\title{
Wild edible plants and mushrooms of the Bamenda Highlands in Cameroon: ethnobotanical assessment and potentials for enhancing food security
}

Evariste Fedoung Fongnzossie ${ }^{1 *}$ (D, Christine Fernande Biyegue Nyangono ${ }^{1}$, Achille Bernard Biwole', Patricia Nee Besong Ebai ${ }^{1}$, Nina Bisi Ndifongwa', Jannet Motove ${ }^{1}$ and Siegfried Didier Dibong ${ }^{2}$

\begin{abstract}
Background: In seasons of food shortage, local communities across Africa use wild edible plants and mushrooms (WEPM) that contribute significantly to food security by supplementing households' diets and providing alternative income. In the Bamenda Highlands of Cameroon, their biodiversity is believed to be rapidly declining as a result of land use change. Despite their potential beneficial values, there has been only limited research on this topic in this area. This study aims to document traditional knowledge related to the use of plants and mushrooms for food purpose by indigenous people of the Bamenda highland.

Method: Ethnobotanical surveys were conducted in 6 localities (Mbengwi, Bafut, Nkwen, Mankon, Bambili, and Widikum) of the Bamenda Highlands of Cameroon, and 121 individuals were interviewed on commonly gathered and eaten WEPMs and their perception on their availability. Respondents were permanent residents selected based on their willingness to participate in the study. Specimens of recorded plants were collected and processed for future identification at the National Herbarium of Cameroon. Their nutritional potentials are discussed based on available literature.
\end{abstract}

Results: A total of 47 species were recorded including leafy vegetable, spices, fruits, roots/tubers, and mushrooms. The top 5 most frequent are Amaranthus sp. (6.6\%), Termitomyces clypeatus (6.4\%), Irvingia gabonensis (5.2\%), Ricinodendron heudelotii (5.1\%), and Aframomum sp. (4.5\%). Leafy vegetable and spices are the most diversified group with 13 species each. All recorded species are important from nutritional and pharmaceutical points. However, many of their values remain uninvestigated, while their natural populations are facing threats of degradation.

Conclusion: WEPMs have great potential to contribute to food and nutritional security in the study area. Sound nutrients and metabolites profiling of poorly known species can enhance their contribution in addressing food insecurity.

Keywords: Ethnobotanical knowledge, Wild edible plants and mushrooms, Bamenda Highlands, Food security

\footnotetext{
* Correspondence: fong_nzossie@yahoo.com

${ }^{1}$ Advanced Technical Teacher's Training School (ENSET), University of Douala, PO BOX 1872, Douala, Cameroon

Full list of author information is available at the end of the article
}

(c) The Author(s). 2020 Open Access This article is licensed under a Creative Commons Attribution 4.0 International License, which permits use, sharing, adaptation, distribution and reproduction in any medium or format, as long as you give appropriate credit to the original author(s) and the source, provide a link to the Creative Commons licence, and indicate if changes were made. The images or other third party material in this article are included in the article's Creative Commons licence, unless indicated otherwise in a credit line to the material. If material is not included in the article's Creative Commons licence and your intended use is not permitted by statutory regulation or exceeds the permitted use, you will need to obtain permission directly from the copyright holder. To view a copy of this licence, visit http://creativecommons.org/licenses/by/4.0/ The Creative Commons Public Domain Dedication waiver (http://creativecommons.org/publicdomain/zero/1.0/) applies to the data made available in this article, unless otherwise stated in a credit line to the data. 


\section{Introduction}

Wild edible plants and mushrooms (WEPMs), according to the Food and Agriculture Organization (FAO), can be defined as "plants and mushrooms that grow spontaneously in self-maintaining populations in natural or seminatural ecosystems and can exist independently of direct human action" [1]. Historically, they have been important dietary components for most societies, and the species and mode of use have evolved in response to local contexts, preferences, and cultures. Since decades, scientists from all over the world have been investigating on wild edible plant resources which are identified to contribute significantly to food security by supplementing households' diets in times of food scarcity and by providing some rare nutrients $[1-5]$. There are evidence from various studies across Africa indicating that wild fruits can supplement the daily diet and substitute for exotic fruits [6]. They are also seen as a particularly important way that households in rural Africa can improve their resilience to environmental change [7].

Cameroon is an ecologically diverse country endowed with high level of biodiversity. The country's natural ecosystems are home to a wide variety of fauna, including 250 species of mammals, 542 fish, 848 birds, 330 reptiles, and 200 amphibians [8]. The country's flora is estimated to comprise about 10,000 species, of which 7 , 850 have already been documented at the National Herbarium of Cameroon [9]. The importance of wild plants in feeding rural populations is very widely recognized through various studies. We can cite the work on a synthesis of knowledge on edible forest fruit trees in Cameroon [10], the study conducted on wild edible plants used by Guiziga people of far North Region of Cameroon [11], the study on indigenous edible fruits in sahelian domain of Cameroon [12], and several studies on non-timber forest products recording many plant species used for various purposes including as food [1322]. Ethnobotanical surveys conducted among 102 sellers of edible wild plants based in 13 markets in the Yaounde City recorded 29 wild edible plant species used in 32 different food recipes [23]. A survey conducted in 4 popular markets of Douala reported a total of 25 wild edible fruit species sold in 4 popular markets of Douala (Littoral Region of Cameroon) [24].

The Bamenda Highlands contain the largest remaining patches of Afromontane forest in Central Africa, consisting of a mosaic of mixed gallery forest, Raphia forests, and savannah grasslands with some of the highest levels of endemism [25]. Previous ethnobotanical surveys showed that traditional societies in this area have always exploited wild edible plants that play a significant role in nutrition, food security, and income generation [26-29]. However, despite their abundance and varied potential beneficial values, wild edible plants and mushrooms have not received much attention similar to domesticated foods, yet they are increasingly seen by most researchers as an important alternative or complementary source of supply to deal with the needs in rural areas. A great majority of these studies have focused on medicinal species, and little emphasis has been paid to wild edible plants. In the Bamenda Highlands, during the last century, major social transformations and the rural exodus causing the concentration of population in large cities, has led to the disappearance of much of the knowledge and traditional practice of collecting spontaneous plants of food interest. Increased forest degradation driven by agriculture and pastoral development is threatening their biodiversity leading to growing poverty and increased vulnerability to food insecurity in many rural communities. However, today we are witnessing worldwide "rediscovery" of wild medicinal and food plants. This ethnobotanical knowledge of wild food plants exist mainly in rural communities that preserve traditional uses. This study proceeded through a substantial investigation of both the present practices and the oral history of the past few decades on traditional utilization of wild edible plants and mushrooms in the study area.

The present investigation was designed and carried out in the Bamenda Highlands of Cameroon to identify and categorize available wild edible plants and mushrooms, assess local perception on their availability, as well as their importance to improve food security among households in the area. We hypothesized that WEPM in this area are important source of nutrients with potentials to improve household's food security.

\section{Materials and Methods}

\section{Study site}

The North-West Region of Cameroon forms the heart of the Bamenda Highlands, lying between latitude $5^{\circ} 4^{\prime}$ and $7^{\circ} 15^{\prime}$ north and longitude $9^{\circ} 30^{\prime}$ and $11^{\circ} 15^{\prime}$ east.

This area has a high human population density of approximately 100-250 people per square kilometer [30]. As a result, human pressure on natural ecosystems over the last century has been the cause of much biodiversity degradation.

The general climate of North-West Region has a rainy season between April and September and a dry season between October and March. Average rainfall is about $2400 \mathrm{~mm}$ and temperature average $23{ }^{\circ} \mathrm{C}$, ranging between $15-32{ }^{\circ} \mathrm{C}$ [31]. This abundant rainfall contributes to the development of agriculture and forest regeneration. This area is known to support high levels of biological diversity and endemism. Three kinds of vegetation are present: lowland forest, mountain forest, and afro-alpine vegetation. The main ethnic groups in the area are of Tikar origin, and agriculture is their main occupation. 
The surveys were carried out in six villages selected based on the accessibility and availability of local informants. These are Mbengwi, Bafut, Nkwen, Mankon, Bambili, and Widikum (Fig. 1).

\section{Sampling procedure}

Respondents were permanent residents and were selected based on their willingness to participate in the study. Our survey took place during the period MarchApril 2017. Overall, 121 individuals were interviewed (Table 1).

\section{Data collection and analysis}

In this study, we followed standard methods in ethnobotanical researches to record the local knowledge on wild edible plants using interviews and field observations. A predesigned questionnaire was used to record the data. Before a formal interview was conducted, verbal or prior informed consent was sought and obtained from the concern village chief or chairman as well as the concerned individual informants by briefing clearly about the objectives of the study to them.

Overall, 121 individuals were interviewed on commonly gathered and eaten wild foods of plant origin (fruits, roots/tubers, mushrooms, leafy vegetables, spices, and others), their availability and conservation status. For each record, information gathered included local name of the plant, part used, and informant's perception on availability of the species. Interviews were mostly conducted in the evenings when most people were back from their various occupations.

After the data collection, the data were organized based on the research questions. Based on their use, the recorded species were classified into different categories namely leafy vegetable, spices, mushroom, roots, tubers, and beverages. The taxonomic richness of each category was determined, and frequency of use citations of species was calculated.

\section{Plants specimen collection and identification}

Voucher specimens of recorded WEPM were collected during field survey to different villages, allotted collection number, and pressed for future identification when returned from the field using various floras of Cameroon. These identifications were confirmed by the National Herbarium of Cameroon. Voucher specimens are kept at the herbarium of the Department of Plant Biology of the University of Douala.

\section{Results}

\section{Consumption habits of wild edible plants}

Of the 121 people interviewed, it appeared that $77.5 \%$ of respondents agreed to consume wild edible plants and mushrooms. Among the eaten wild plant species, spices are the most consumed, and tubers are the least consumed (Fig. 2). From analysis, $85 \%$ of them agree that they are important contribution during difficult times of food shortage.

Taxonomic diversity of wild edible plants and mushrooms A total of 47 species were recorded (Table 2). They include leafy vegetable (13 species), spices (13 species), fruits (12 species), mushroom (6 species), roots and tubers ( 4 species), and beverages ( 1 species). The top 10 most frequently cited are Amaranthus sp. (6.6\%), Termitomyces clypeatus R. Heim (6.4\%), Irvingia gabonensis (Aubry-Lecomte ex O'Rorke) Baill. (5.2\%), Ricinodendron heudelotii (H.E.Baillon) J.B.Pierre ex E.M.Heckel. (5.1\%), Aframomum sp. (4.5\%), Raphia farinifera (Gaertn.) Hyl. (4.2\%), Termitomyces letestui (Pat.) Heim. (4.1\%), Termitomyces sp. (4\%), Xylopia aethiopica (Dunal) A. Rich. (3.8\%), and Afrostyrax lepidophyllus Mildbr. (3.3\%).

\section{Local perception of the availability of wild edible plants and mushroom}

Our results showed that wild edible plants in the Bamenda Highlands are under serious threat, as perceived by local informants. More than $60 \%$ of respondents believe availability of WEPM is getting smaller than before, while $23 \%$ think the availability has not changed, and $14 \%$ said availability is larger than before (Fig. 3).

Main reasons of scarcity of WEPM are excessive collection and other human activities including overgrazing, agricultural land expansion, uncontrolled bushfires, etc.

\section{Discussion}

Knowledge and use of wild edible plants and mushrooms in Bamenda Highlands

Cameroon is a culturally diverse country consisting of over 250 ethnic groups, and the cuisine significantly varies by ethnic group and region. Wild foods are essential components for these dishes and the regional cuisine. In the Bamenda Highlands of Cameroon, the Tikares appears to be the most populous ethnic group, and they were the first to settle on the Bamenda region [32]. According to anthropologists, they originated from northern Cameroon and migrated southwards and westwards in the eighteenth and nineteenth centuries to their current locations in the Western Grassfields (Bamenda Highlands) and Eastern Grassfields (Fumban) and the Tikar Plain of Bankim [33]. Despite the scarcity of ethnobotanical literature on wild foods, indigenous communities in this area have gathered wild edible plants and mushrooms for centuries as a strategy to complement their crop-livestock subsistence systems. Each community group has made particular choices among 


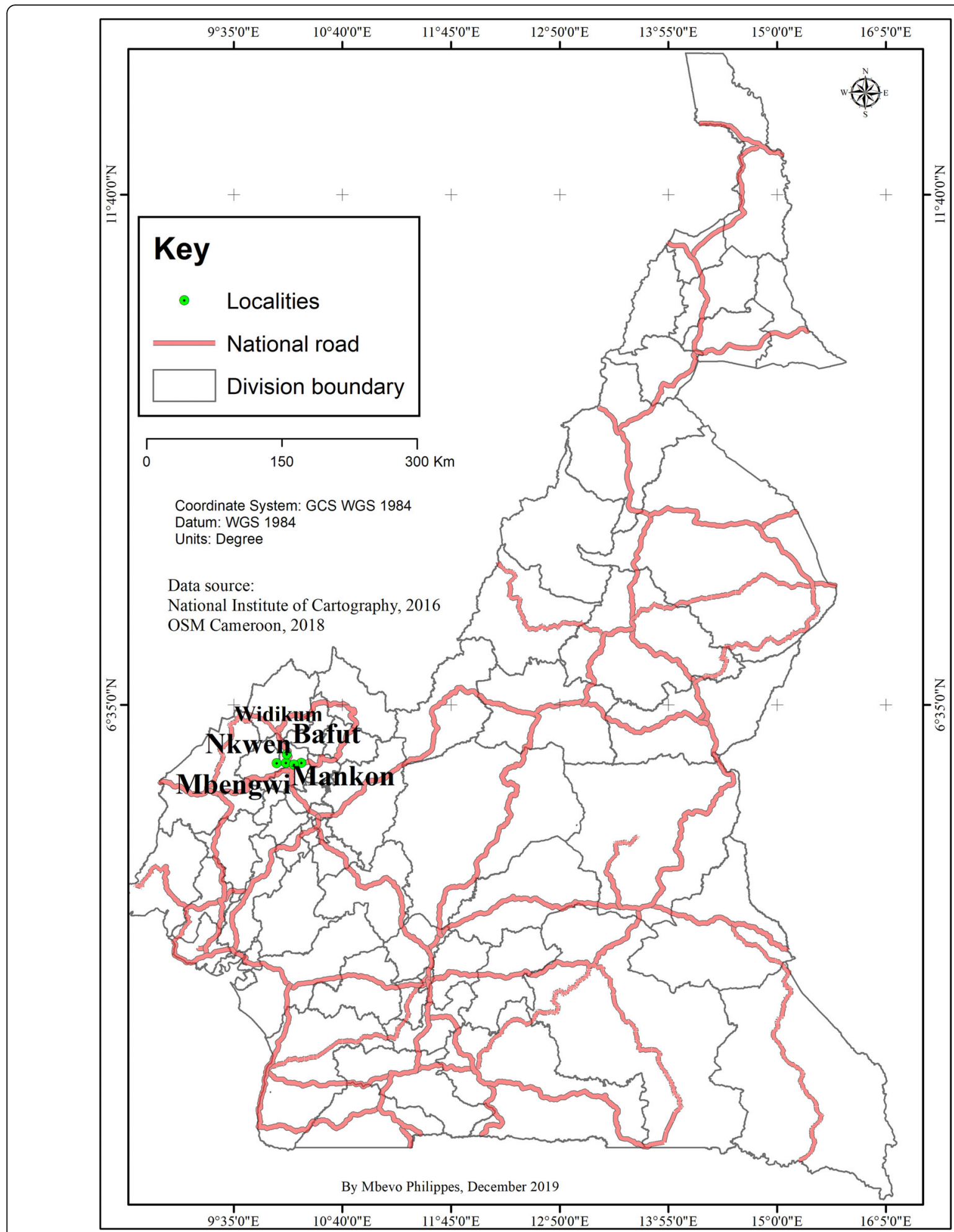

Fig. 1 Location of the study area

the wild food resources available, and this utilitarian relationship between indigenous communities and the WEPM can be contextualized in space and time. As it was described in temperate ecosystems, the dynamics of this relationship can vary depending on species availability, site accessibility, cultural acceptability, traditional ecological knowledge, migration, changes in lifestyle, and other socio-ecological processes [34]. These factors, 
Table 1 Sociodemographic characteristics of respondents

\begin{tabular}{lll}
\hline Characteristics & Number & Percentage \\
\hline Distribution by villages & 30 & 24.8 \\
Mbengwi & 30 & 24.8 \\
Widikum & 16 & 13.2 \\
Bafut & 15 & 12.4 \\
Nkwen & 18 & 14.9 \\
Mankon & 12 & 9.9 \\
Bambili & & \\
Distribution by gender & 45 & 37.2 \\
Female & 76 & 62.8 \\
Male & & \\
Distribution by age group & 4 & 3.3 \\
Below 20 & 79 & 65.3 \\
20-30 & 32 & 26.4 \\
$31-40$ & 6 & 5 \\
$41-50$ & &
\end{tabular}

according to [35], can determine the acceptability or a possible replacement of wild foods with modern foods.

In this study, 47 species were recorded. Some, including Ricinodendron heudelotii, Piper guineensis, Cola sp., Tetrapleura tetraptera, Xylopia aethiopica, and Canarium schweinfurthii, have been reported in previous surveys on non-timber forest products in Tikar Plain [36]. Others like bush mango (Irvingia gabonensis), njansang (Ricinodendron heudelotii), eru (Gnetum africanum), and kola nuts (Cola spp.) are also among the key nontimber forest products of Central Africa [37].

The number of species recorded during this survey does not certainly captures all the diversity of wild edible plants and mushrooms growing in this study area, as their availability rely on seasons. There is generally a relatively high importance of wild edible plants in the rainy season. The period of the survey coincided with the beginning of the rainy season when some species, although not yet providing edible parts, is re-sprouting, flowering, and fruiting. A crossseasonal investigation will be required to capture the diversity of wild edible plants and mushrooms consumed in the study area.

Also, as argued by several authors, age, gender, and other sociocultural variables are likely to influence access to wild plant resources and the traditional ecological knowledge of wild foods [38].

\section{Nutritional potentials of wild edible plants and mushroom recorded}

Several studies emphasize on the high nutritional importance of wild edible plants [39-42]. This is true for the species in different groups of WEPM recorded. Their seasonal relative importance greatly impacts the food and nutritional insecurity copying ability of households. Previous studies have confirmed that in times of food scarcity, they make human diets more diverse and add flavor, vitamins, and minerals [43].

\section{Vegetables}

The highly exploited wild vegetable Gnetum spp., locally called "eru" is very rich in proteins and minerals $(\mathrm{Na}, \mathrm{K}$, $\mathrm{Ca}, \mathrm{Mg}, \mathrm{Fe}$ ) and contains all essential amino acids [44].

Waterleaf (Talinum triangulare) is reported to be very rich in carbohydrates, protein, steroid, oil, b-Carotene, crude fibers, and minerals like $\mathrm{Ca}, \mathrm{Mg}, \mathrm{Na}$, and $\mathrm{K}$ [45].

Elemental analysis in $\mathrm{mg} / 100 \mathrm{~g}$ (DW) of leaves of Amaranthus hybridus was done by previous studies [46]. These authors indicated that the leaves contained sodium (7.43), potassium (54.20), calcium (44.15), magnesium (231.22), iron (13.58), zinc (3.80), and phosphorus (34.91). The vitamin composition of the leaves in $\mathrm{mg} / 100 \mathrm{~g}$ (DW) was as follows: carotene (3.29), thiamine (2.75), riboflavin (4.24), niacin (1.54),

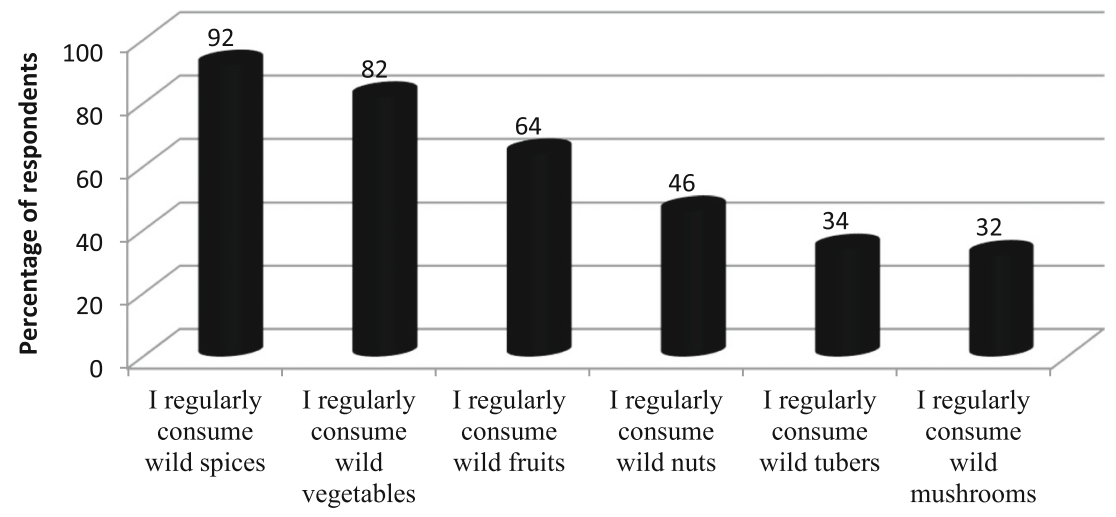

Fig. 2 Citation frequency of consumption habits wild edible plants and mushrooms 
Table 2 Taxonomic list of the recorded species

\begin{tabular}{|c|c|c|c|c|c|c|}
\hline Local name & $\begin{array}{l}\text { Locality/ } \\
\text { language }\end{array}$ & Scientific name & Family & Category & $\begin{array}{l}\text { Voucher } \\
\text { specimen }\end{array}$ & $\begin{array}{l}\text { Citation } \\
\text { frequency }\end{array}$ \\
\hline Masangha, marsareh & Mendakwe & Acanthaceae & Acanthaceae & Vegetable & FFE027 & 0.8 \\
\hline Frechooh & Widikum & Aframomum sp. & Zingiberaceae & Fruit & FFE011 & 4.5 \\
\hline Alelock, Echap & Be'feu-Bafut & Afrostyrax lepidophyllus Mildbr. & Huaceae & Spice & FFE016 & 3.3 \\
\hline Contry green, Etang & $\begin{array}{l}\text { Pidgin, } \\
\text { Mbengwi }\end{array}$ & Amaranthus hybridus L. & Amaranthaceae & Vegetable & FFE0026 & 2.1 \\
\hline Contri green, Etang & $\begin{array}{l}\text { Pidgin, } \\
\text { Mbengwi }\end{array}$ & Amaranthus sp. & Amaranthaceae & Vegetable & FFE018 & 6.6 \\
\hline $\begin{array}{l}\text { Ekarebang, ekereket, } \\
\text { ngwetuat }\end{array}$ & Bambili & Annona muricata $\mathrm{L}$. & Annonaceae & Fruit & FFE012 & 3.2 \\
\hline Black, Gejabe & $\begin{array}{l}\text { Mankon- } \\
\text { Alakuma }\end{array}$ & Canarium schweinfurthii Engl. & Burseraceae & Fruit & FFE019 & 1.2 \\
\hline Cola, tamtsi & Wum & Cola acuminata (P. Beauv.) Schott and Endl & Sterculiaceae & Fruit & FFE037 & 1.3 \\
\hline Cola, tamtsi & Bafut & Cola anomala K. Schum. & Sterculiaceae & Fruit & FFE050 & 2.3 \\
\hline $\begin{array}{l}\text { Monkey Cola, } \\
\text { awulawela }\end{array}$ & Muganka & Cola lepidota K. Schum & Sterculiaceae & Fruit & FFE034 & 2.1 \\
\hline Lemgambelle & Bali Nyonga & Corchorus olitorius L. & Malvaceae & Vegetable & FFE014 & 0.5 \\
\hline Monkey sugarcane & Bafut & Costus afer Ker Gawl. & Costaceae & $\begin{array}{l}\text { Roots/ } \\
\text { tubers }\end{array}$ & FFE025 & 0.4 \\
\hline Ecute/bush yams & Bafut & Dioscorea spp. & Dioscoreaceae & $\begin{array}{l}\text { Roots/ } \\
\text { tubers }\end{array}$ & FFE021 & 0.3 \\
\hline Bitter cola/okogon & Bali Nyonga & Garcinia kola Heckel & Clusiaceae & Fruit & FFE039 & 2.2 \\
\hline Eru & Santa & Gnetum spp. & Gnetaceae & Vegetable & FFE042 & 1.6 \\
\hline $\begin{array}{l}\text { Mfume, njap, njap, bush } \\
\text { mango }\end{array}$ & $\begin{array}{l}\text { Pidgin- } \\
\text { Furawa }\end{array}$ & $\begin{array}{l}\text { Irvingia gabonensis (Aubry-Lecomte ex } \\
\text { O'Rorke) Baill. }\end{array}$ & Irvingiaceae & Fruit/spice & FFE033 & 5.2 \\
\hline Bayeng, bedeneng & Akwaya & Lentinus squarrosulus Mont. & Polyporaceae & Mushroom & FFE013 & 1.0 \\
\hline Mango & Mankon & Mangifera indica L. & Anacardiaceae & Fruits & FFE017 & 0.1 \\
\hline Mangwah, manpang & Bafut & Mentha sp. & Lamiaceae & Vegetable & FFE015 & 1.4 \\
\hline Adondon, Suuh & Bafut & Monodora myristica Dunal & Annonaceae & Spice & FFE022 & 2.5 \\
\hline Tecjaw & Widikum & Moondia whitei (Hook.f.) Skeels & Apocynaceae & $\begin{array}{l}\text { Roots/fruit/ } \\
\text { spice }\end{array}$ & FFE043 & 0.7 \\
\hline Funom & Batibo & Occimum basilicum L. & Lamiaceae & $\begin{array}{l}\text { Spice/ } \\
\text { vegetable }\end{array}$ & FFE046 & 2.7 \\
\hline Fesong, efop & Pining & Occimum gratissimum $\mathrm{L}$. & Lamiaceae & $\begin{array}{l}\text { Spice/ } \\
\text { vegetable }\end{array}$ & FFE031 & 2.5 \\
\hline Begele, Bejabe & Santa & Passiflora edulis Sims & Passifloraceae & Fruit & FFE059 & 0.4 \\
\hline Azong grass & Widikum & Penisetum purpureum Schumach & Poaceae & Vegetable & FFE056 & 0.2 \\
\hline Wild tomato & Bafut & Physalis angulata $\mathrm{L}$. & Solanaceae & Fruits & FFE044 & 0.3 \\
\hline Sop, Bush pepper, tone & Bafanji & Piper guineensis Schumach. \& Thonn. & Piperaceae & Spice & FFE029 & 1.6 \\
\hline White pepper & Bafut & Piper nigrum L. & Piperaceae & Spice & FFE045 & 2.5 \\
\hline Feboh & Mendakwe & Pleurotus pulmonarius (Fr.) Quel. & Pleurotaceae & Mushroom & FFE030 & 2.7 \\
\hline Ankup & Mankon & Raphia farinifera (Gaertn.) Hyl. & Arecaceae & $\begin{array}{l}\text { Beverage, } \\
\text { fruits }\end{array}$ & FFE047 & 4.2 \\
\hline Djansang, lesah & Ndop & $\begin{array}{l}\text { Ricinodendron heudelotii (H.E.Baillon) } \\
\text { J.B.Pierre ex E.M.Heckel. }\end{array}$ & Euphorbiaceae & Spice & FFE032 & 5.1 \\
\hline Bush onion & Bambili & Scorodophleus zenkeri Harms & Mimosaceae & Spice & FFE053 & 1.1 \\
\hline \multirow{2}{*}{$\begin{array}{l}\text { Black jack, Njama } \\
\text { njama }\end{array}$} & Nkwen & Solanum nigrum L. & Solanaceae & Vegetable & FFE051 & 3.3 \\
\hline & & Solanum melongena $\mathrm{L}$. & Solanaceae & Spice & FFE023 & 0.9 \\
\hline
\end{tabular}


Table 2 Taxonomic list of the recorded species (Continued)

\begin{tabular}{|c|c|c|c|c|c|c|}
\hline Local name & $\begin{array}{l}\text { Locality/ } \\
\text { language }\end{array}$ & Scientific name & Family & Category & $\begin{array}{l}\text { Voucher } \\
\text { specimen }\end{array}$ & $\begin{array}{l}\text { Citation } \\
\text { frequency }\end{array}$ \\
\hline \multirow[t]{2}{*}{ Sun flower } & \multirow[t]{2}{*}{ Pidgin } & Helianthus annum L. & Asteraceae & Vegetable & FFE040 & 0.1 \\
\hline & & Syzygium guineensis (Wild.) DC. & Myrtaceae & Fruits & FFE035 & 0.5 \\
\hline Nmborie & Wum & Talinum trianguare (Jacq.) Wild. & Portulacaceae & Vegetable & FFE020 & 0.6 \\
\hline Agreuh & Ndop & Termitomyces clypeatus R. Heim & Tricholomataceae & Mushroom & FFE057 & 6.4 \\
\hline Boh & Widikum & Termitomyces letestui (Pat.) Heim. & Tricholomataceae & Mushroom & FFE024 & 4.1 \\
\hline Efin & Bambui & Termitomyces sp. & Tricholomataceae & Mushroom & FFE038 & 4.0 \\
\hline Beteh & Mankon & Termitomyces ourantiacus (R. Heim) R. Heim. & Lyophyllaceae & Mushroom & FFE036 & 2.2 \\
\hline Eshuk, Ngon & Nkwen & $\begin{array}{l}\text { Tetrapleura tetraptera (Schumach. and } \\
\text { Thonn) }\end{array}$ & Mimosaceae & Spice & FFE054 & 1.4 \\
\hline Erita & Bambili & Vernonia amygdalina Delile & Asperaceae & Vegetable & FFE049 & 2.2 \\
\hline Atamah & Santa & Vernonia calvoana (Hook.f.) Hook.f. & Asteraceae & Vegetable & FFE038 & 0.9 \\
\hline Jensen & Banso & Vernonia guineensis Benth. & Asteraceae & $\begin{array}{l}\text { Roots/ } \\
\text { tubers }\end{array}$ & FFE058 & 0.5 \\
\hline Ferebah, enkirgelinic & Bambui & Xylopia aethiopica (Dunal) A. Rich. & Annonaceae & Spice & FFE052 & 3.8 \\
\hline Etangebenut & Santa & Xylopia sp. & Annonaceae & Spice & FFE048 & 0.3 \\
\hline
\end{tabular}

pyridoxine (2.33), ascorbic acids (25.40), and -tocopherol (0.50). These authors also reported 17 amino acids (isoleucine, leucine, lysine, methionine, cysteine, phenylalmine, tyrosine, threonine, valine, alanine, arginine, aspartic acid, glutamic acid, glycine, histidine, proline, and serine) detected in leaves of this species. Alkaloid, flavonoid, saponin, tannins, phenols, hydrocyanic acid, and phytic acid composition were 3.54, $0.83,1.68,0.49,0.35,16.99$, and 1.32 , respectively. These evidences are indication that the leaves of Amaranthus hybridus are important source of nutrients, minerals, vitamins, amino acids and phytochemicals, and low levels of toxicants.

For Corchorus olitorius, the proximate and mineral composition of leaves were investigated in Nigeria
[47] and showed that the leaves contained $18.38 \pm$ $0.32 \%$ ash, $12.54 \pm 0.10 \%$ crude protein, $11.99 \pm$ $0.50 \%$ crude lipid, and $19.56 \pm 0.18 \%$ available carbohydrate. Their energy value reported was $200.78 \pm$ $3.54 \mathrm{kcal} / 100 \mathrm{~g}$. On the other hand, their mineral content comprises potassium $(2814.15 \pm 8.08 \mathrm{mg} / 100$ g) and magnesium $(76.69 \pm 0.13 \mathrm{mg} / 100 \mathrm{~g})$ as dominant elements, $\mathrm{Na}(54.56 \pm 0.42 \mathrm{mg} / 100 \mathrm{~g}), \mathrm{Ca}(30.55$ $\pm 0.05 \mathrm{mg} / 100 \mathrm{~g}), \mathrm{P}(6.68 \pm 0.02 \mathrm{mg} / 100 \mathrm{~g}), \mathrm{Cu}(2.52$ $\pm 0.02 \mathrm{mg} / 100 \mathrm{~g}), \mathrm{Fe}(19.53 \pm 0.09 \mathrm{mg} / 100 \mathrm{~g}), \mathrm{Mn}$ $(5.95 \pm 0.04 \mathrm{mg} / 100 \mathrm{~g})$, and $\mathrm{Zn}(4.71+0.01 \mathrm{mg} / 100$ g). These findings support the use of Corchorus olitorius leaves are rich sources of potassium, iron, copper, manganese, and zinc as well as high energy values essential in human nutrition. Antinociceptive/anti-inflammatory, anti-

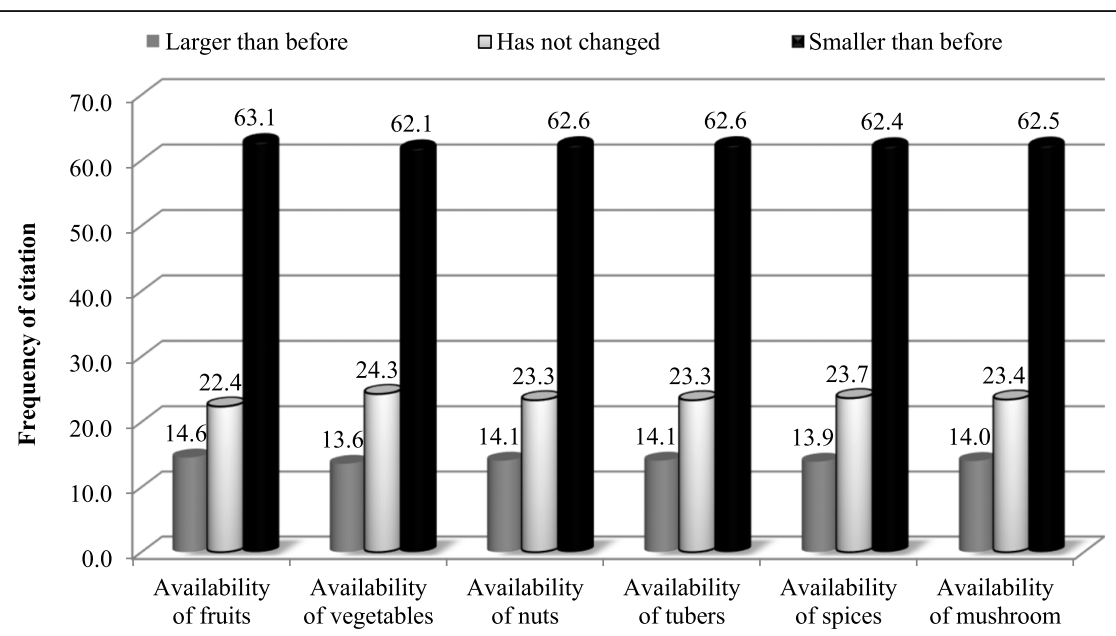

Fig. 3 Respondent's perception on availability of wild edible plants and mushrooms 
tumor, antipyretic, carminative, demulcent, laxative, stimulant, and stomachic properties were also reported for this species [48].

Strong free radical scavenging activity was reported for Vernonia calvoana, and the authors of this study concluded that $V$. calvoana could serve as source of strong dietary antioxidants [49]. Its amino acid composition compare favorably with that of WHO protein standard [50], and Vernonia calvoana is also rich source of carotenoids (between 30 and $41.5 \mathrm{mg} / 100 \mathrm{~g}$ DW), vitamin C (between 137.5 and $197.5 \mathrm{mg} / 100 \mathrm{~g} \mathrm{DW}$ ), and dietary fiber (24.9-30.1 g/100 g DW).

\section{Spices}

Afrostyrax lepidophyllus was investigated for its biological activity and phytochemical composition [51]. Using 3 different extracts, these authors reported tannin content of the order of $2.35 \pm 0.3,10.68 \pm 0.1,7$, and 78 $\pm 0.2 \mathrm{mg}$ eq Cat/g DM. That of anthocyanins were 0.79 $\pm 0.04,0.65 \pm 0.02,1.65 \pm 0.07$, and $0.18 \pm 0.03 \mathrm{mg}$ eq $\mathrm{C} 3 \mathrm{GE} / \mathrm{g}$ MS. These findings support the antioxidant, anti-inflammatory, and anti-xanthine oxidase activity of Afrostyrax lepidophyllus seeds used in the human diet.

Fruits of Mondia whitei contain antioxidant vitamins $\mathrm{C}$ and $\mathrm{E}$ which had values of $14.50 \mathrm{mg} / 100 \mathrm{~g}$ and 2.45 $\mu \mathrm{g} / \mathrm{g}$, respectively [52]. Potassium and sodium are the most abundant mineral elements. The roots of this species are attracting the interests of cosmeceutical, nutraceutical, and pharmaceutical industries. They are traditionally used for the treatment of anorexia, stress, bilharzia, and sexual dysfunction as well as for general aches and pains. The efficacy of most of these claims have been analyzed several researchers who investigated in the biological activities Mondia whitei roots and reported antimicrobial, anti-inflammatory, and anthelmintic as well as aphrodisiac efficacy [53].

Piper guineensis is a rich source of calcium (179.52 \pm $0.11 \mathrm{mg} / 100 \mathrm{~g})$, potassium $(98.52 \pm 0.1011 \mathrm{mg} / 100 \mathrm{~g})$, and phosphore $(217.70 \pm 0.41 \mathrm{mg} / 100 \mathrm{~g})$, and vitamin $\mathrm{B} 2$ and $\mathrm{C}$ [54].

Chemical profiling of Xylopia aethiopica revealed the presence of different phytochemicals of various physiological and biological actions. The fruit was reported to contain $38.72 \pm 0.61 \%$ fiber, $26.08 \pm 1.41 \%$ carbohydrates, $18.47 \pm 0.05 \%$ protein, $6.73 \pm 0.01 \%$ lipid, $6.02 \pm 0.84 \%$ moisture, and $4.00 \pm 0.02 \%$ ash, and mineral analysis showed the abundance of some mineral elements in Xylopia aethiopica fruit like calcium, potassium, magnesium, sodium, irons, phosphorus, zinc, manganese, chromium, and copper [55]. It was also reported the presence of alkaloids, cardiac glycosides, saponins, tannins, flavonoids, polyphenols, and reducing sugars, vitamins $\mathrm{A}, \mathrm{C}$, and $\beta$-carotene, all bioactive substances that may be beneficial to health [56].

\section{Fruits}

Nutritional potential of Canarium schweinfurthii was investigated in Plateau State in Nigeria [57]. They indicated crude fat of the fruit as $64.04 \%$, protein $6.39 \%$, fibers $16.37 \%$, and carbohydrates $3.85 \%$, respectively. Mineral analysis revealed that phosphorus and sodium levels were 1.74 and $1.369 \mathrm{mg} / 100 \mathrm{~g}$, respectively. These authors suggested that Canarium schweinfurthii is nutritive despite the presence of some low levels antinutritive components like oxalate. The final products will contain even less.

The presence of various phytochemical constituents like flavonoids, tannins, phenol, glycosides, fatty acids, and alkaloids was reported in the fruit of Passiflora edulis [58], as well as anti-inflammatory, anticonvulsant, antimicrobial, anticancer, antidiabetic, antihypertensive, anti-sedative, and antioxidant properties.

The leaves of Physalis angulata were investigated for their potentials in alleviating micronutrient deficiency [59]. The study found that Physalis angulata fruits have crude protein content of $10.97 \%$, sodium $689.48 \mathrm{mg} / 100$ $\mathrm{g}$, and manganese $21.60 \mathrm{mg} / 100 \mathrm{~g}$. Amino acid analysis indicated the presence of isoleucine, valine, phenylalanine, tyrosine, and leucine. The reported concentration of phytate/Zn supports its potential into food-based strategy to alleviate zinc malnutrition.

\section{Roots and tubers}

The antiprostate cancer and antiangiogenic activity of the roots of Vernonia guineensis were demonstrated, supporting the use of the tubers of this plant for the treatment of prostate cancer [60].

\section{Beverage}

Records from the database of Plant Resource of Tropical Africa (PROTA) indicate that the fruit pulp of Raphia farinifera contains about $24 \%$ oil. The major fatty acids in seed oil are palmitic acid, oleic acid, and linoleic acid. The main sterol is $\beta$-sitosterol. The fruit pulp has shown antibacterial activity against Staphylococcus aureus but not against the gram-negative bacteria Escherichia coli, Pseudomonas aeruginosa, and Salmonella typhi; it also had no activity against the fungi Candida albicans and Aspergillus niger.

It is thus clear from various screening of the recorded plants that almost all of them are important from nutraceutical points. Many of the recorded plants are of rich nutritional value as sources of micro and macro elements, roughage, protein, and amino acids without anti-nutritional factors [61]. Local communities in the Bamenda Highlands thus 
derive important nutrients from these plants. However, some are lacking scientific nutritional knowledge, and many of their values remain either uninvestigated or undocumented because their products are used locally without being reflected in national or international markets. Therefore, systematic documentation of indigenous knowledge regarding the identity and use of wild edible plants is an urgent concern because both biological resources and indigenous knowledge are diminishing with high destruction and a growing disinterest among the younger generation.

\section{Conclusion}

With respect to our stated hypothesis, we recorded 47 species of wild edible plants and mushrooms commonly gathered by the local population in the Bamenda Highlands use. Overall, the study shows that these species are largely consumed by local populations in the study area and play important role in household diets. They have great potential to contribute to food and nutritional security. However, for some of the recorded species, many of their values remain either uninvestigated or undocumented. In addition, the status of many of the commonly gathered and eaten species is declining in study area, driven by deforestation, bushfires, and over harvesting. This study strongly recommends actions aimed at promoting the conservation of wild edible plants as part of food security strategy by households. Sound nutrients and metabolites profiling of poorly known species need to be investigated to enhance their contribution in addressing food insecurity. Further, it is recommended to continue investigating on the factors that may determine the knowledge and use of wild edible plants.

\section{Acknowledgements}

The authors wish to express their gratitude to all the people of study localities for their cooperation and assistance.

\section{Authors' contributions}

EFF and NBCF conceived and designed the experiment study. EFF, NN, and JM performed the data collection. EFF, NBCF, and EBP analyzed the data. EFF wrote the paper. All authors read and approved the final manuscript.

\section{Funding}

The authors did not receive any funds for covering the costs to conduct this research or to publish in open access.

\section{Availability of data and materials \\ Plant specimens were deposited in the Département de Biologie et Physiologie Végétale Université de Douala.}

\section{Ethics approval and consent to participate}

As mentioned in our data collection section, prior informed consent was sought from our respondent before the data collection.

\section{Consent for publication}

Not applicable

\section{Competing interests}

The authors declare that they have no competing interests.

\section{Author details}

${ }^{1}$ Advanced Technical Teacher's Training School (ENSET), University of Douala, PO BOX 1872, Douala, Cameroon. ${ }^{2}$ Faculty of Science, Department of Plant biology, University of Douala, PO BOX 24157, Douala, Cameroon.

Received: 9 July 2019 Accepted: 19 February 2020

Published online: 04 March 2020

\section{References}

1. Heywood VH. Use and potential of wild plants in farm households. FAO Farm Systems Management Series. Rome, Italy: Food and Agriculture Organisation; 1999. 113 p.

2. Mosango M, Szafranski F. Plantes sauvages à fruits comestibles dans les environs de Kisangani (Zaïre). J. Agric. Tradit. Bot. Appl. 1985:XXXIl:177-90

3. Mbula Itumba O. Contribution a l'étude des plantes alimentaires sauvages de Yasikia (PK 31 route Opala, PO, RDC). In: Mémoire pour l'obtention du grade de Gradué en Sciences Option Biologie, Orientation Ecologie et Gestion des Ressources Végétales. Kisangani: Université de; 2014. 36 p.

4. Matabaro Amani Y, Habamungu Shalukoma S, Nteranya B, Kazadi Minzangi F, Koleramungu Cimanuka O, Cirimwami TG. Inventory of wild food plants in Irhambi-Katana, Bugorhe and Miti Districts, South-Kivu, DR Congo. Int J Innov Sci Res. 2016;20(1):163-70.

5. Malela KE, Miabangana ES, Petit J, N'zikou JM, Scher J. Enquête ethnobotanique sur les fruits comestibles de la flore spontanée de la République du Congo. Int J Pure Appl Biosci. 2016;4(2):346-57.

6. Boedecker J. The contribution of wild edible plants to local diets of women in the Lama Forest in Benin. Master's dissertation, Faculty of Bioscience Engineering. Gent: Universiteit Gent; 2013. p. 98.

7. Shumsky SA, Hickey GM, Pelletier B, Johns T. Understanding the contribution of wild edible plants to rural socialecological resilience in semiarid Kenya. Ecol Soc. 2014;19(4):34.

8. Fomete NT, Tchanou Z. La gestion des écosystèmes forestiers du Cameroun à l'aube de l'an 2000. Yaoundé, Cameroun: rapport provisoire UICN; 1998. $148 \mathrm{p}$.

9. Onana JM. 2011. The vascular plants of Cameroon. A taxonomic checklist with IUCN assessments. Flore du Cameroun vol 39 "occasional volume". 195 p.

10. Eyog Matig O, Ndoye O, Kengue J, Awono A. Editeurs. Les Fruitiers Forestiers Comestibles du Cameroun. Cotonou: International Plant Genetic Resources Institute. 2006. p. 220.

11. Hamawa Y. Wild edible plants used by Guiziga people of far north region of Cameroon. Int J Med Aromatic Plants. 2013:3(2):136-43.

12. Todou G, Doudou K, Vroumsia T. Diversity and local transformation of indigenous edible fruits in sahelian domain of Cameroon. J Anim Plant Sci. 2017;33(2):5289-300

13. Doucet JL. and Koufani A. 1997. Etude des produits secondaires végétaux de la forêt de Kompia (Cameroun). Utilisation, inventaires, régénération, commercialisation et gestion durable. Faculté des Sciences Agronomiques de Gembloux-Herbier National du Cameroun, projet «Mise en place de forêts communautaires en périphérie de la Réserve de faune du Dja, Cameroun», $71 \mathrm{pp}$.

14. Ndoye, O. Ruiz-Perez M. and Eyebe A. 1997. The markets of non-timber forest products in the humid forest zone of Cameroon. Overseas Development Institute, Rural Development Forestry Network, Odi Network Paper 22c.

15. Tabuna, H. 1999. Le Marché des Produits Forestiers Non Ligneux de l'Afrique Centrale en France et en Belgique. CIFOR occasional paper n 19. 35 p. ISSN 0854-9818.

16. Fankap, R., Doucet, J.L. and Dethier, M. 2001. Valorisation des produits forestiers non ligneux en forêt communautaire. — In: Delvingt, W. (Ed.), La forêt des hommes. Terroirs villageois en forêt tropicale africaine. Les presses agronomiques de Gembloux, pp. 145-168.

17. Mbolo, M. 2002. La collecte et l'analyse des données statistiques sur les produits tbrestiers non ligneux. Une étude pilote au Canteroun Progrtrnrme d'Anrénagentent des forêts dans les pays ACP 137 p.

18. Vermeulen C, Jean DOUCET, J.L. Conservation and sustainable use of nontimber forest products in favour of local communities within integrated forest management in Central Africa. Proceedings of the International Symposium on Tropical Forests in a Changing Global Context. Brussels: 
Royal Academy of Overseas Sciences United Nations Educational, Scientific and Cultural Organization; 2004. p. 267-80.

19. Tchatat, M. \& Ndoye, O. 2006. Étude des produits forestiers non ligneux d'Afrique centrale : réalités et perspectives. Bois et Forêts des Tropiques, 2006, N $N^{\circ} 288$ (2) : 27-39.

20. Manirakiza, D. 2007. Etude de la consommation d'Irvingia spp. (mangue sauvage) et Ricinodendron heudelotii (Njansang) à Yaoundé et Libreville. Rapport projet Renforcement de la sécurité alimentaire en Afrique Centrale à travers la gestion et l'utilisation durable des produits forestiers non ligneux. 27p.

21. Awono, A., Djouguep, A., Zapfack, L. \& Ndoye, O. 2009. The potential of Irvingia gabonensis: can it contribute to the improvement of the livelihoods of producers in Southern Cameroon? Int J Soc Forestry, 2(1):67-85 ISSN 1979-2611, www.ijsf.org.

22. Lescuyer, G. 2010. Importance économique des produits forestiers non ligneux dans quelques villages du Sud-Cameroun. Bois et forêts des Tropiques, $N^{\circ} 304$ ( 2 ) : 15-24

23. Betti JL, Manga Ngankoué C, Dibong SD, Eboulé SA. Etude ethnobotanique des plantes alimentaires spontanées vendues dans les marchés de Yaoundé, Cameroun. Int J Biol Chem Sci. 2016;10(4):1678-93.

24. Dibong SD, Mpondo Mpondo $E$, Ngoye A. Vulnérabilité des espèces à fruits sauvages vendus dans les marchés de Douala (Cameroun). J Anim Plant Sci. 2011;11(3):1435-41.

25. Ingram V and Nsom JA. Plant and animal guide for the Western Cameroon Highlands. Yaoundé: Technical report WHINCONET. 2007. p. 15.

26. Focho DA, Muh CN, Mendi GA, Fongod AN, Fonge BA. Ethnobotanical survey of trees in Fundong, Northwest Region, Cameroon. J Ethnobiol Ethnomed. 2009;5:17.

27. Abdou Bouba A, Ponka R, Goudoum A, Njintang Yanou N, Mehanni AbulHamd ES, Montet D, Scher J, Mbofung MC. Amino acid and fatty acid profile of twenty wild plants used as spices in Cameroon. Am J Food Sci Tech. 2016:4(2):29-37.

28. Njouonkou AL, De Crop E, Mbouombouo Mbenmoun A, Tonjock RK, Biyé $E H$, Verbeken A. Diversity of edible and medicinal mushrooms used in the Noun Division of the West Region of Cameroon. Int J Med Mushrooms. 2016:18(5):387-96

29. Tonjock RK, Nkengmo AA, Theobald MN, Ache NA, Afui MM. Species richness and traditional knowledge of macrofungi (mushrooms) in the awing forest reserve and communities, Northwest Region, Cameroon. J Mycol. 2017;2017:9 p.

30. Lyong ES, Kahdzefee JT and Nsai MPD. 2015. Field surveys on the medicinal wildlife species of the North West Region of Cameroon; their usages and the means of acquisition Final Report. Rufford small grants. 27 p.

31. Ndoh MI, Bitondo D, Azibo BR. Climate variability and change in the Bamenda Highlands of North Western Cameroon: perceptions, impacts and coping mechanisms. Br J Appl Sci Tech. 2016;12(5):1-18.

32. Ngengong ET. From friends to enemies: inter-ethnic conflict amongst the Tikars of the Bamenda Grassfields (North West Province of Cameroon) C. 1950-1998. Norway: Master Thesis, Faculty of Social Sciences University of Tromsø; 2007. 96p

33. Nyamnjoh FB. 2007. African-Americans seeking Tikar origin in Cameroon: notes on multiple dimensions of belonging. http://www.nyamnjoh.com/ consulted on January 26, 2020

34. Barreau A, Ibarra JT, Wyndham FS, Rojas A, Kozak RA. How can we teach ou children if we cannot access the forest? Generational change in Mapuche knowledge of wild edible plants in Andean temperate ecosystems of Chile Source. J Ethnobiol. 2016;36(2):412-32.

35. Delang CO. The role of wild food plants in poverty alleviation and biodiversity conservation in tropical countries. Progress in Development Studies. 2006;6:275-86.

36. Zapfack L, Ngobo NM. A participatory survey and inventory of timber and non timber forest products of the Tikar Plain. Cameroun: A Report for CARPE Yaounde, Cameroon, University of Yaoundé and IITA; 2001. 57p.

37. Clark $L E$, Sunderland TCH. The key non-timber forest products of Central Africa: state of the knowledge, SD Publication Series, Technical Paper No 122. Office of Sustainable Development, Bureau for Africa, U.S. Washington, D.C: Agency for International Development; 2004. 199 p.

38. Gallois S, Duda R, Reyes-García V. Local ecological knowledge among Baka children: a case of children's culture. J Ethnobiol. 2017;37(1):60-80.

39. Burlingame B. Wild nutrition. J Food Comp Anal. 2000:13(2):99-100.
40. Ogoye-Ndegwa C, Aagaard-Hansen J. Traditional gathering of wild vegetables among the Luo of Western Kenya - a nutritional anthropology project. Ecol Food Nutr. 2003;42:69-89.

41. Keller GB, Mndiga H, Maass B. Diversity and genetic erosion of traditional vegetables in Tanzania from the farmer's point of view. Plant Genet Res. 2006:3:400-13.

42. Alencar NL, de Sousa Araújo TA, de Amorim EL, de Albuquerque UP. The inclusion and selection of medicinal plants in traditional pharmacopoeias - evidence in support of the diversification hypothesis. Econ Bot. 2010;64(1):68-79.

43. Okafor JC. Edible indigenous woody plants in the rural economy of the Nigeria forest zone. In: Okali DUU, editor. The Nigeria Rainforest Ecosystem Proceedings of MAB Workshop on the Nigeria Rainforest Ecosystem. Nigeria: University of Ibadan; 1979.

44. Fasuyi AO. Nutritional potentials of some tropical vegetable leaf meals: chemical characterization and functional properties. Afr J Biotechnol. 2006;5: 49-53.

45. Aja PM, Okaka ANC, Onu PN, Ibiam U, Urako AJ. Phytochemical composition of Talinum triangulare leaves. Pak J Nutr. 2010;9(6):527-30.

46. Akubugwo IE, Obasi NA, Chinyere GC, Ugbogu AE. Nutritional and chemical value of Amaranthus hybridus L. leaves from Afikpo, Nigeria. Afr J Biotechnol. 2007:6(24):2833-9.

47. Idirs S, Yisa J, Ndamitso M. Nutritional composition of Corchorus olitorius leaves. Anim Prod Res Adv. 2010;5. https://doi.org/10.4314/apra.v5i2.49827.

48. Mahbubul I. Biochemistry, medicinal and food values of jute (Corchorus capsularis L. and C. olitorius L.) leaf: a review. Int J Enhanced Res Sci Techn Eng. 2015;2(11):35-44.

49. Eneji Egbung G, Atangwho TJ, Kiasira NB, Iwara A, Igile GO. Antioxidant activity of the inflorescents of Vernonia calvoana growing in Yakurr local government area of Cross River State, Nigeria. Glob j pure appl sci. 2016;22:141-6.

50. Aba Ejoh R, Djuikwo VN, Gouado I, Mbofung CM. Nutritional components of some non-conventional leafy vegetables consumed in Cameroon. Pak J Nutr. 2007;6(6):712-7.

51. Namkona AF, Bolevane OSF, Moustapha F, Worowounga X, Ngaissona P, Koane JN, Syssa-Magalé. Biological activities and phytochemical analysis of extracts Afrostyrax lepidophyllus Mildbr, Seeds. J Phytopharmacology. 2017; 6(2):102-6.

52. Aremu AO, Cheesman L, Finnie JF, Van Staden J. Mondia whitei (Apocynaceae): a review of its biological activities, conservation strategies and economic potential. S Afr J Bot. 2011;77 (4:960-71.

53. Okonkwo C, Ogu A. Nutritional evaluation of some selected spices commonly used in the south-eastern part of Nigeria. J Biol, Agric Healthc. 2014;4(15):2014.

54. Besong EE, Balogun ME, Djobissie SFA, Mbamalu OS, Obimma JN. A review of Piper guineense (African black pepper). ljppr.Human. 2016;6(1):368-84.

55. Chinedu I, Ojochenemi EY, Nkeiruka Gl, Ifeoma SU, Ogochukwu JO. Chemical composition of Xylopia aethiopica fruits. Am J Physiol, Biochem Pharmacol. 2018;7(2):48-53.

56. Okwari OO, Nneli RO, Osim EE, Dasofunjo K. Preliminary studies on aqueous fruit extract of Xylopia Aethiopica obtained in Calabar Nigeria. Aust J Basic Appl Sci. 2013;7(9):67-71.

57. Nyam MA, Makut MD, Itelima JU, Daniel AM. Nutritional potential of the fruits of black olive (Canarium schweinfurthii Linn) from Plateau State, Nigeria. Pak J Nutr. 2014;13(6):335-9.

58. Zas P, John S. Diabetes and medicinal benefits of Passiflora edulis. World J Pharm Res. 2016;5(3):453-65.

59. Aliero AA, Usman H. Leaves of ground cherry (Physalis angulata L.) may be suitable in alleviating micronutrient deficiency. Food Sci Technol. 2016;4(5): 89-94.

60. Toyang NJ, Wabo HK, Ateh EN, Davis H, Tane P, Kimbu SF, Sondengam LB, Bryant J. In vitro anti-prostate cancer and ex vivo antiangiogenic activity of Vernonia guineensis Benth. (Asteraceae) tuber extracts. J Ethnopharmacol. 2012;14(3):866-71.

61. Afui MM, Abwe MN, Lawrence MN. Assessment of nutritional composition of wild vegetables consumed by the people of Lebialem Highlands, South Western Cameroon. Food Nutr Sci. 2017;2017(8):647-57.

\section{Publisher's Note}

Springer Nature remains neutral with regard to jurisdictional claims in published maps and institutional affiliations. 